\title{
Indonesian Language
}

National Cancer Institute

\section{Source}

National Cancer Institute. Indonesian Language. NCI Thesaurus. Code C153959.

An Austronesian language that is a standardized register of Malay and the official language of Indonesia. 